\title{
Fine-scale spatial heterogeneity of invertebrates within cryoconite holes
}

\author{
Krzysztof Zawierucha · Jakub Buda • Diego Fontaneto - Roberto Ambrosini • \\ Andrea Franzetti $\cdot$ Mariusz Wierzgoń $\cdot$ Michał Bogdziewicz
}

Received: 22 January 2019/Accepted: 22 February 2019/Published online: 11 March 2019

(C) The Author(s) 2019

\begin{abstract}
Cryoconite holes (water-filled reservoirs) are considered ecologically simple ecosystems but represent biological hotspots of biodiversity on glaciers. In order to check for fine-scale spatial distribution of metazoans on the bottom of the holes, in this study, we analysed three groups of grazing invertebrates as a model: tardigrades, rotifers, and mites. We addressed differences within cryoconite holes comparing the distribution of invertebrates within and between separate holes and between
\end{abstract}

Handling Editor: Télesphore Sime-Ngando.

Electronic supplementary material The online version of this article (https://doi.org/10.1007/s10452-019-09681-9) contains supplementary material, which is available to authorized users.

K. Zawierucha $(\bowtie) \cdot$ J. Buda

Department of Animal Taxonomy and Ecology, Adam

Mickiewicz University, Poznań, Umultowska 89,

61-614 Poznań, Poland

e-mail: k.p.zawierucha@gmail.com

D. Fontaneto

Water Research Institute, National Research Council of Italy, Largo Tonolli 50, 28922 Verbania, Italy

R. Ambrosini

Department of Environmental Science and Policy, University of Milan, Via Celoria 26, 20131 Milan, Italy glaciers at a worldwide scale. We divided each cryoconite hole into three sampling zones (established in relation to water flow on a glacier) and collected nine subsamples within cryoconite holes on glaciers in the Arctic (Longyearbreen), Norway (Blåisen), the Alps (Forni) and maritime Antarctic (Ecology Glacier). Generally, we found no consistent difference in sampling zones within cryoconite holes, which suggests homogeneity on the hole floors. However, we did find strong differences and high heterogeneity between subsamples, even within the same zone. Invertebrate densities ranged between 52 and 426 individuals per $\mathrm{ml}$ in subsamples collected from the same hole. We found from zero to four trdigrade species in the cryoconite hole on Longyearbreen. Our results show that benthic animals in cryoconite holes
A. Franzetti
Department of Earth and Environmental Sciences
(DISAT), University of Milano-Bicocca, Piazza della
Scienza, 1 - 20126 Milano, Italy
M. Wierzgoń
Department of Botany and Nature Protection, Faculty of Biology and Environmental Protection, University of Silesia in Katowice, Jagiellońska 28, 40-032 Katowice, Poland

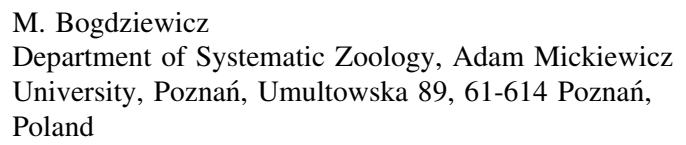


in various climatic zones have heterogeneous spatial distribution, even if no preference could be highlighted for upstream versus downstream areas with respect to water flow. The distribution of invertebrates may result from ecosystem disturbance by flushing water and animals' active movement. Cryoconite holes, usually considered to be simple ecosystems, seem to be complex habitats where hidden spatial heterogeneity may affect abundance and diversity of organisms.

Keywords Extreme habitats - Polar and alpine ecosystems · Random distribution - Rotifera · Supraglacial environments $\cdot$ Tardigrada

\section{Introduction}

Cryoconite is the dark mineral and organic dust on the surface of glaciers. It plays an important role in the functioning of supraglacial ecosystems by reducing ice albedo and, along with microbial communities, forming dark bioreactors-cryoconite granules (Cook et al. 2016a, b; Hodson et al. 2008; Takeuchi et al. 2001a, b; Wharton et al. 1985). In places where the albedo is diminished by the presence of cryoconite, water-filled reservoirs, i.e. cryoconite holes, form on the surface (Hodson et al. 2008; Wharton et al. 1985). Cryoconite holes are the most biologically active environments on glaciers and constitute dynamic extreme ecosystems that are affected by flushing water, high UV doses, and seasonal as well as daily freezing (e.g. Anesio and Laybourn-Parry 2012; Cook et al. 2015; Franzetti et al. 2016; Hodson et al. 2008; Zawierucha et al. 2019).

Cryoconite holes represent an entire ecosystem with a consistent occurrence of primary producers (algae, cyanobacteria) and secondary consumers, including grazers (unicellular eukaryotes and microscopic invertebrates such as tardigrades and rotifers), interacting during the creation and maintenance of cryoconite holes (Hodson et al. 2008; Zawierucha et al. 2015). Benthic microbial communities are known to control organic matter production (Stibal et al. 2010), and even to influence the morphological evolution of cryoconite holes (Cook et al. 2016a).

The ecology and biology of cryoconite holes as ecosystems have been the subject of intensive studies
(Cook et al. 2015; Darcy et al. 2018; Pittino et al. 2018; Poniecka et al. 2018; Zawierucha et al. 2018). The majority of recent works focused on the diversity, physiology and metabolism of bacteria and algae (Yallop et al. 2012; Grzesiak et al. 2015; Gawor et al. 2016) in the processes forming cryoconite granules (Takeuchi et al. 2001b; Uetake et al. 2019), on interactions between surface ice structures, cryoconite holes, weathering crust and organisms, on the socalled biocryomorphology (Cook et al. 2016a), and on the contamination of supraglacial ecosystems (Ferrario et al. 2017). Similar studies analysed the entire cryosphere, i.e. the ecosystem of glaciers, studying spatial differences in prokaryote communities within and between glaciers (Edwards et al. 2011), as well as the dispersal and behaviour of microorganisms (Cook et al. 2016a; Musilova et al. 2015; Franzetti et al. 2017a; Perkins et al. 2017). Studies on the cryosphere ranged from those performed on a large scale, e.g. concerning glaciers (Smith et al. 2017; Darcy et al. 2018), to the ones conducted on a small-scale, e.g. investigating cryoconite granules (Takeuchi et al. 2001a, b; Uetake et al. 2019).

Regarding spatial patterns of the occurrence of species, Edwards et al. (2011) showed that bacteria communities in cryoconite holes differ in taxonomic composition between glaciers. While exploring potential processes driving taxonomic differences, Pittino et al. (2018) demonstrated that prokaryote communities change throughout time, between years and seasons. Musilova et al. (2015) showed that cryoconite bacterial composition remained stable in the Greenland Ice Sheet during ablation periods, but that rapid turnovers in bacterial composition happened at the beginning of summer during snow melting. Mieczan et al. (2013) demonstrated differential vertical distribution of ciliates in Antarctic cryoconite holes. Sommers et al. (2019) investigated differences in bacteria and algae species richness and biomass between sediments and water in Antarctic closed cryoconite holes. The authors found evidence that holes with greater richness of taxa and biomass showed less partitioning of taxa by the sediments versus the water and suggested the probability of sediment microbes being mixed into the water is higher from thicker sediments. However, the study was conducted only in closed (not dynamic) cryoconite holes in a single geographical locality (the Dry Valleys of Antarctica), and, as the authors stressed, 
future work should include more sampling of cryoconite holes at a finer spatial scale, and characterise the communities of the sediments (Sommers et al. 2019). Indeed, until now there have been no studies on organism distribution within a cryoconite hole floor.

The distribution of biota in cryoconite holes has been suggested to be driven by external environmental factors such as ice melting or rain, which influence mixing, redistribution and erosion of sediments (Zawierucha et al. 2018, 2019). Understanding the factors shaping the diversity and densities of organisms in an ecosystem is key to determining the power of our inference on such an ecosystem (Kang and Mills 2006; Stec et al. 2016). Owing to a relevant role of cryoconite holes in the functioning of the cryosphere, including their impact on carbon flow or glacier surface melting (Hodson et al. 2007; Fountain et al. 2004), highlighting the commonalities in the patterns of occurrence of organisms across different cryoconite holes, different glaciers, and different geographical areas is a crucial step towards understanding the mechanisms sustaining cryoconite holes as ecosystems.

The distribution of organisms in ecosystems is determined by a number of variables. For example, in other terrestrial environments such as soils, where microscopic organisms interact at a similar spatial scale as in cryoconite holes, both the size of soil particles and the combination of aggregates result in a diversified environment with heterogeneity readily displayed at different scales (Franklin et al. 2002; Franklin and Mills 2003; Green et al. 2004; Grundmann and Debouzie 2000). Hidden heterogeneity of a habitat may mask significant ecological processes. In soil ecosystems, for instance, a considerable number of niches can be contained within tiny spaces (Curtis et al. 2002; Kang and Mills 2006), and cryoconite holes may constitute their justifiable analogues. Cryoconite holes contain the most complex microbial assemblies in a glacial biome (e.g. Hodson et al. 2008) with microscopic invertebrates as top consumers (Zawierucha et al. 2015). In addition, even within a single cryoconite hole, different ecological niches may form for instance close to the hole walls or in the centre of the floor, which is influenced by light (Cook et al. 2016a).

The aim of our study was to find generalities in the distribution of the biota within cryoconite holes. To do so, we addressed the differences within each hole comparing the distribution of microscopic invertebrates within and between separate holes and between glaciers at a worldwide scale, including Arctic, Subarctic, Alpine, and Antarctic glaciers, and sampling holes of different size and with varying levels of water. Our expectations were that invertebrate densities and diversity, regardless of differences in the geography and ecology of a cryoconite hole, vary on the floor of the hole, and that such distribution does not differ randomly but may be structured by ecological processes, particulary through a gradient with higher densities in the part of cryoconite holes oriented towards a glacier terminus due to surface water gently flushing towards the glacier end and passively transporting organisms. We focused on microscopic invertebrates - our model organisms, which are frequent and abundant top consumers in cryoconite holes of polar and alpine regions (De Smet and Van Rompu 1994; Porazińska et al. 2004; Zawierucha et al. 2015, 2016a), and which are characterised by potentially more stable and traceable densities than prokaryotes or unicellular eukaryotes.

\section{Methods}

Study locations

Glaciers were chosen to represent different areas of the world (Fig. 1). The four selected glaciers were from: the Arctic (Longyearbreen, in Svalbard), the Subarctic (Blåisen, in Norway), the temperate mountains (Forni, in the European Alps) and Antarctica (Ecology Glacier, in maritime Antarctica, King George Island). Longyearbreen (WGS84 coordinates: $78^{\circ} 10^{\prime} 49^{\prime \prime} \mathrm{N}$, $15^{\circ} 30^{\prime} 21^{\prime \prime} \mathrm{E}$ ) is a land-terminating, cold glacier located near the town of Longyearbyen, in the catchment of Adventfjorden, western Spitsbergen. The northeastfacing Longyearbreen descends from over $1000 \mathrm{~m}$ to approximately $250 \mathrm{~m}$ a.s.l. The area of Longyearbreen is $2.7 \mathrm{~km}^{2}$ (Etzelmüller et al. 2000). Blåisen $\left(60^{\circ} 33^{\prime} 74^{\prime \prime} \mathrm{N}, 7^{\circ} 29^{\prime} 49^{\prime \prime} \mathrm{E}\right)$ is a northern outlet valley glacier from Hardangerjøkulen (Central Southern Norway). The glacier covers $4.9 \mathrm{~km}^{2}$, and its elevation ranges between 1370 and $1850 \mathrm{~m}$ a.s.l. (Dahl and Nesje 1994). The Forni Glacier $\left(46^{\circ} 12^{\prime} 30^{\prime \prime} \mathrm{N}\right.$, $\left.10^{\circ} 13^{\prime} 50^{\prime \prime} \mathrm{E}\right)$ is an Italian temperate valley glacier belonging to Ortles-Cevedale Group in the Alps. The area of Forni is $10.83 \mathrm{~km}^{2}$ (Azzoni et al. 2017). Its 


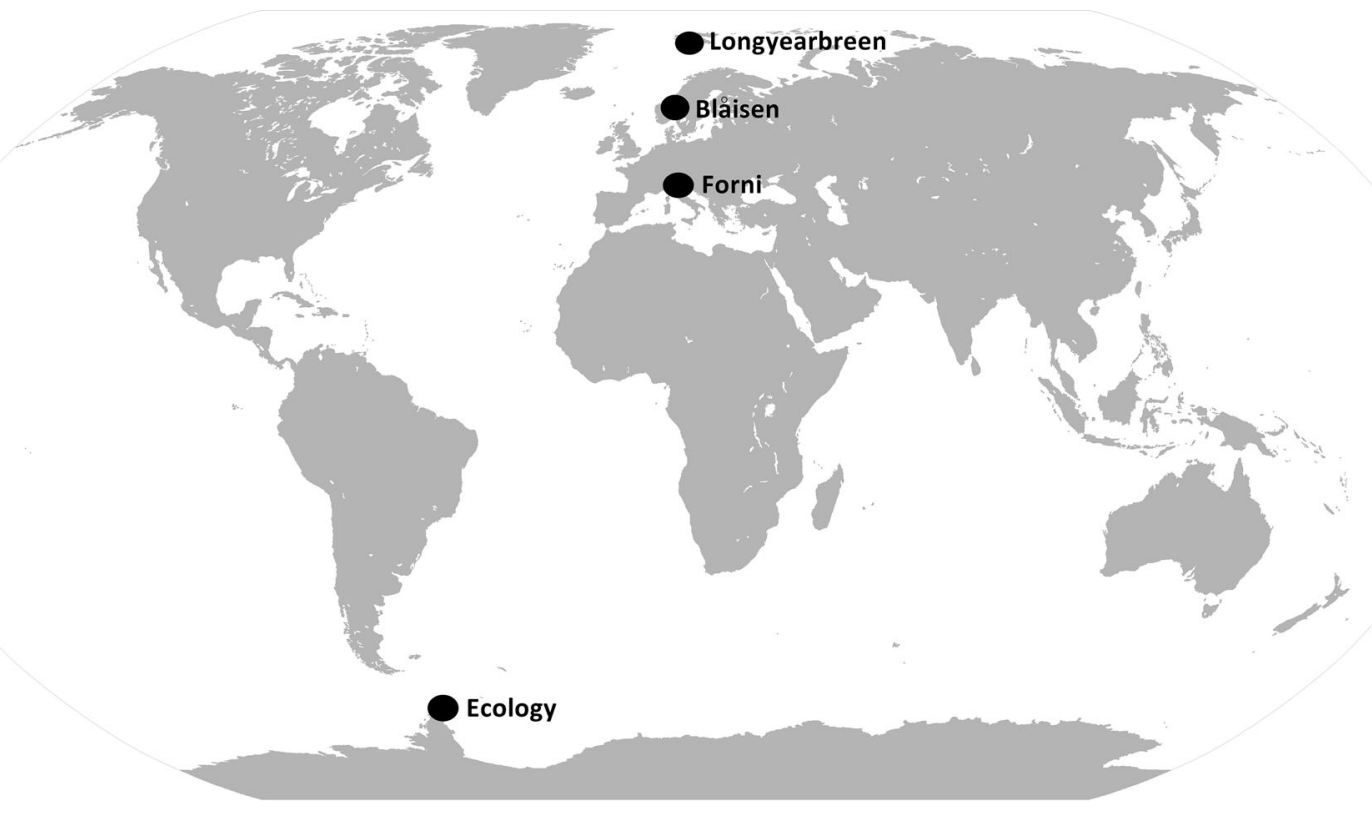

Fig. 1 Map of the world with sampling sites

elevation ranges between 2600 and $3670 \mathrm{~m}$ a.s.l. The Ecology Glacier $\left(62^{\circ} 11^{\prime} 92^{\prime \prime} \mathrm{S}, 58^{\circ} 30^{\prime} 78^{\prime \prime} \mathrm{W}\right)$ is located on King George Island in the South Shetland Archipelago. The Ecology Glacier is a valley-tidewater glacier located on the western shore of Admiralty Bay. The area of the glacier is $5 \mathrm{~km}^{2}$ (Pętlicki et al. 2017).

The four glaciers represent different geographical regions (three glaciers are from Europe and one is from Antarctica), and different environments [two glaciers are from areas where light and temperature follow a seasonal cycle (Longyearbreen, Ecology Glacier) and two from where they follow both a seasonal and a daily cycle (Blåisen, Forni)]. Thus, any commonalities in invertebrate distribution notwithstanding such extreme geographical and ecological differences will represent an intrinsic feature of the ecosystem of cryoconite holes.

\section{Sampling strategy}

A total of 14 cryoconite holes was analysed. Samples were collected from: four cryoconite holes on Longyearbreen at 360-380 m a.s.l. in August 2016, three cryoconite holes on Blåisen at 1300-1400 m a.s.l. in August 2018, three cryoconite holes on Forni at 2600-2700 $\mathrm{m}$ a.s.1. in July 2018, and four cryoconite holes on Ecology Glacier at 69-265 m a.s.l. in February 2018. The holes were of size between 12 and $25 \mathrm{~cm}$ of the longer chord, and with water content ranging between 3 and $15 \mathrm{~cm}$ of vertical depth.

The samples were collected in order to analyse the spatial distribution of invertebrates on the bottom of the holes. Nine subsamples were collected from each cryoconite hole: three for each of three rows. When cryoconite holes were elliptical, subsamples were collected along the longer axis of each cryoconite hole (Fig. 2). From the cryoconite hole perspective, the first

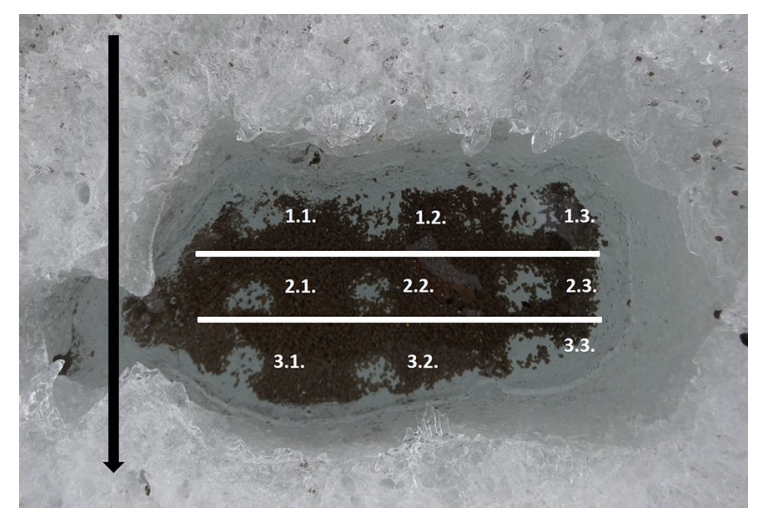

Fig. 2 Example of sampling design in a cryoconite hole from Longyearbreen. The arrow indicates glacier terminus 
row was always located towards the snowline, the second row in the middle, and the third row located towards the glacier terminus. Cryoconite holes on each glacier were similar in size but with different shape. On Longyearbreen, they were circular, elliptical and irregular, on Blåisen and Forni circular or irregular. On Ecology Glacier, being irregular and shallow, the holes resembled puddles. Nine subsamples were collected from each cryoconite hole, except for one hole on Lyongearbreen where only eight subsamples were collected, with one missing subsample in the first row. Thus, a total of 125 subsamples were investigated. The area of the collected sediments in one subsample ranged between 1 and $1.5 \mathrm{~cm}^{2}$ (depending on the size of the hole). Each subsample was collected with a separate disposable plastic Pasteur pipette and transferred into a 15-ml plastic test tube. The samples were collected to harvest the sediment from the bottom of the cryoconite holes, to search for invertebrates. Following the collection, the samples were preserved in $96 \%$ ethanol.

In laboratory, the whole cryoconite material was poured onto plastic Petri dishes. In order to aid dish scanning, parallel lines were engraved with a pencil on the outer bottom of each dish, so that at the magnification of 40 times, the space between the lines fell into the range encompassed by the visual field of a stereomicroscope. Such an approach was previously used and described by Dastych (1980) and Stec et al. (2015).

All the animals found in each of the subsamples were identified and grouped into three categories: Acari, Rotifera and Tardigrada. For rotifers, no further taxonomic identification was possible, whereas for mites and tardigrades, the identification was performed to the most detailed taxonomic level of morphological species, both for already known species and for potentially new or unidentified species (Zawierucha et al. 2016a).

Invertebrate counts from each sample were converted into density of individuals per $1 \mathrm{ml}$ of cryoconite.

Data analysis

Using generalised linear mixed models (GLMMs) implemented via the glmmTMB package (Brooks et al. 2017), in R Development (R Core Team 2017), we tested whether the density of the taxonomic groups differs among the rows within each cryoconite hole. Due to different motility, feeding behaviour, size and shape of invertebrates found in the samples, which might have influenced their dispersal within and between the holes, for each group we built a separate, negative binomial model (using a log-link function) with the group count as response variable, cryoconite hole ID as random effect, and a row ID (indicating row position within a hole, i.e. whether it was the top, middle or bottom row) as a fixed effect. The analysis was repeated for each glacier we sampled (i.e. four times). However, to explore generalities on all the glaciers, and on all groups of animals, we built a negative binomial model (using a log-link function) with the animal count as the response variable, glacier ID and cryoconite hole ID nested into glacier ID as random effects, and two fixed effects: a row ID, animal group (i.e. mites, rotifers or tardigrades) along with their interaction as a fixed effects. In all the models, the volume of the sample was used as an offset. We tested for statistical significance of the fixed factors with the likelihood ratio test.

The framework described above involves several consecutive statistical tests on the same data. Thus, we used conservative Bonferroni-corrected alpha-values to maintain the correct experiment-wise error rate (Forstmeier et al. 2017). We ran five tests for each group, so that the level of significance for each test was adjusted to alpha $=0.05 / 5=0.01$.

Rotifers from the collected subsamples were preserved in alcohol, consequently their identification to species level using methods of classical taxonomy was impossible. Tardigrades on Forni, and mites on the Ecology Glacier were represented by one species only. Therefore, a comparison of species frequency (expressed in \%) between sampling points was done only for tardigrades found on Longyearbreen.

\section{Results}

Contrary to our expectations, we did not find any common differences in invertebrate densities between the rows of subsamples I-III (gradient in relation to water flow with expectedly higher densities of animals in the part of cryoconite holes oriented towards the glacier terminus). Likewise, additional model considering all the glaciers and animals together, showed no 
Table 1 Summary of the negative binomial GLMMs tested for the differences in abundance among rows (see "Methods" for details)

\begin{tabular}{lllll}
\hline Glacier & Tardigrada & Rotifera & Acari & Total \\
\hline Lyongearbreen & $\chi^{2}=2.25, p=0.32$ & $\chi^{2}=0.77, p=0.68$ & NA & $\chi^{2}=1.23, p=0.54$ \\
Blåisen & NA & $\chi^{2}=7.29, p=0.03$ & NA & NA \\
Forni & $\chi^{2}=0.18, p=0.91$ & NA & NA & NA \\
Ecology & NA & $\chi^{2}=4.15, p=0.12$ & $\chi^{2}=1.09, p=0.58$ & $\chi^{2}=2.91, p=0.23$ \\
\hline
\end{tabular}

Degrees of freedom equal five in all models. NA indicates that the particular group was not present in the samples at the glacier (or present in very limited abundance that precluded modelling, i.e. tardigrades on Blåisen). No significant effects at a Bonferronicorrected $\alpha=0.01$ were detected

Fig. 3 The density of invertebrates in three parallel rows on the cryoconite hole floor: a, b Tardigrada and Rotifera on Longyearbreen, c Rotifera on Blåisen, d Tardigrada on Forni, e, f Rotifera and Acari on Ecology. Row ID indicate row position within each hole: 1 top row, 2 middle row, 3 bootom row (toward the glacier terminus). The boxes denote the 25 th, 50 th, and 75 th percentiles; the whiskers indicate the furthest data points within a 1.5 interquartile range; the grey circles refers to sampling points within rows; and the dark circles refer to data points beyond a 1.5 interquartile range
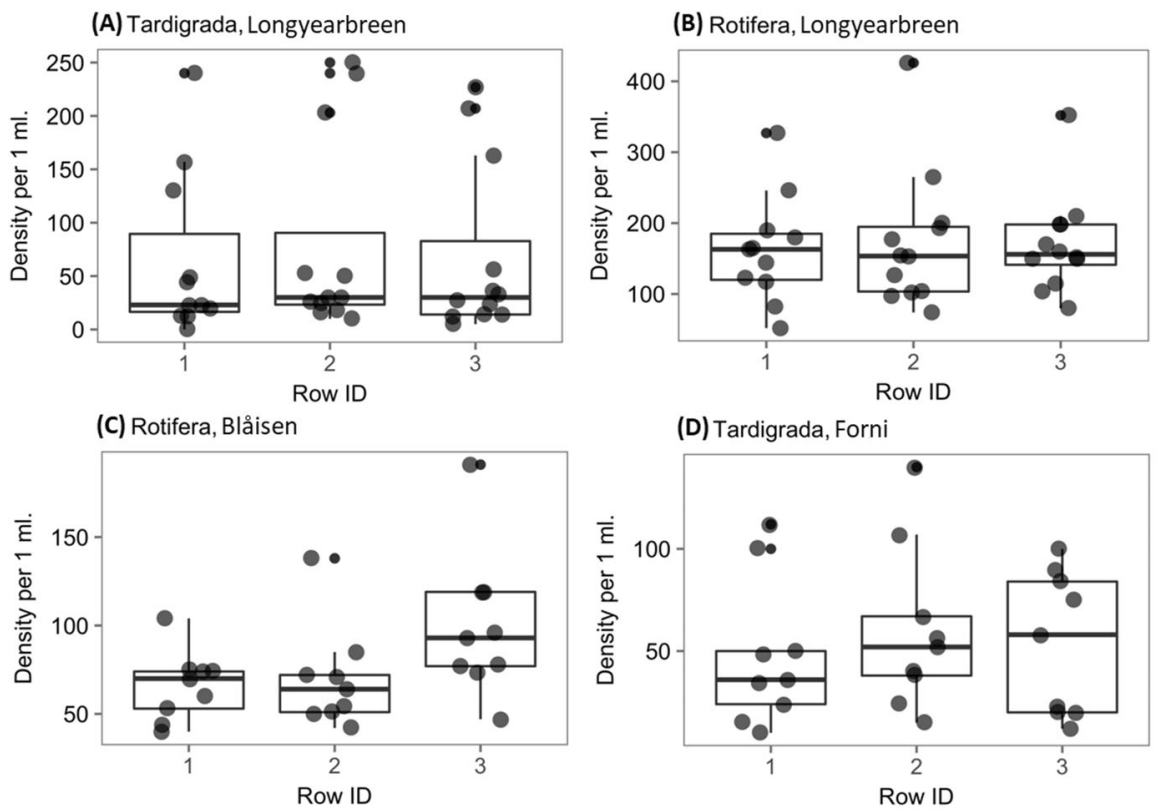

(E) Rotifera, Ecology

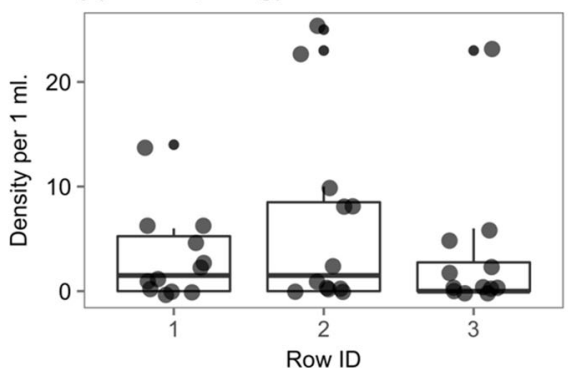

(F) Acari, Ecology

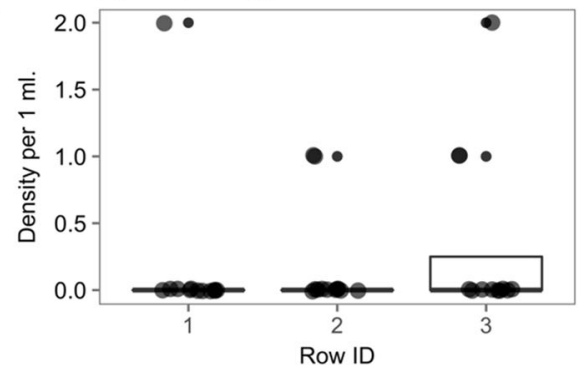

relation between animal densities and row position (Table 1, Fig. 3a-f, Figures S2-S5).

Invertebrate densities, regardless of variations in geography and the type of glacier, differ on the floor of cryoconite holes. The density of animals varied considerably among the subsamples taken within the same hole (Fig. 3, Figures S2-S5). For the Arctic Longyearbreen glacier, in the case of rotifers, the largest absolute difference in the density between two subsamples taken within the same hole was 374 ind./ $\mathrm{ml}$ (maximum: 426 ind./ml vs. minimum: 52 ind./ml) and for tardigrades it was $110 \mathrm{ind} . / \mathrm{ml}$ (maximum: 230 
ind./ml vs. minimum: 130 ind./ml). For the Scandinavian Blåisen glacier, the greatest absolute difference in the density of rotifers between two subsamples taken within the same hole was $151 \mathrm{ind} . / \mathrm{ml}$ (maximum: 191 ind./ml vs. minimum: 40 ind./ml). On the alpine Forni Glacier, the difference in the density of tardigrades between two subsamples was 74 ind./ml (maximum: $84 \mathrm{ind} . / \mathrm{ml}$ vs. minimum: $10 \mathrm{ind} . / \mathrm{ml}$ ). For the Antarctic Ecology glacier, in the case of rotifers, the most prominent absolute difference in density was 22 ind./ $\mathrm{ml}$ (maximum: 25 ind./ml vs. minimum: 3 ind./ml), and for mites it was 1 ind./ml (maximum: 2 ind./ml vs. minimum: 1 ind./ml).

We did not find commonality in the diversity and dominance of invertebrates in cryoconite holes. On Longyearbreen, tardigrades (Pilatobius sp., Isohypsibius sp., Hypsibius sp., Hypsibius cf. dujardini) and unidentified rotifers were found. On Blåisen, mostly bdelloid rotifers were located with few tardigrades (Pilatobius sp., excluded from the main analysis owing to its presence in just two subsamples). Cryoconite holes on Forni were characterised by exclusive predominance of tardigrade Hypsibius klebelsbergi Mihelčič, 1959. On the Ecology Glacier, only bdelloid rotifers and mites were found (species designation will be described elsewhere). Tardigrades found in the study belong to typical grazers, microbivorous, and herbivorous/omnivorous species. Rotifers are most probably filter feeders, and, in turn, mites are suspension feeders.

Tardigrades were identified to morphospecies level, and four species were found on Longyearbreen. A microbivorous grazer, Pilatobius sp. was the dominant species in cryoconite holes, followed by an herbivorous species, Hypsibius sp. (Fig. 4a-d). Species richness in subsamples within the same cryoconite hole ranged from zero to four (Fig. 4a). In cryoconite hole no. 3 the abundance of Pilatobius sp. in subsamples always exceeded 50\% reaching even 100\% (Fig. 4c). We could not identify any general pattern of differences in species occurrence or abundance between the rows of subsamples.

\section{Discussion}

Our results show that animals in cryoconite holes have heterogeneous fine-scale spatial distribution on a hole bottom, with each subsample being different from the nearby ones, even if no preference could be highlighted for upstream versus downstream areas in relation to water flow. The results demonstrate that invertebrate densities varied considerably among the subsamples taken within the same cryoconite hole. These findings imply that our power of inference on biota abundance and diversity in cryoconite holes depends on the number of subsamples taken within a hole or the amount of collected cryoconite, especially in larger cryoconite holes $(>12 \mathrm{~cm}$ in diameter, like the ones we analysed), which offer more space for animals to move around actively or passively. Furthermore, the occurrence and abundance of animals on glaciers do not differ among the rows of subsamples collected along the longer axis of the holes, implying that invertebrate distribution in the holes does not show a general pattern.

In environmental studies, important interactions between organisms and their environment are often hard to detect, especially in highly complex environments such as forests, rivers or ponds (Bogdziewicz et al. 2017; Peacor and Werner 1997; Schmitz and Suttle 2001). Even though cryoconite holes are often considered to be ecologically simple ecosystems (Koshima 1987; Hodson et al. 2008), they are characterised by complex microbial communities with high biodiversity (e.g. Gokul et al. 2016). Cryoconite holes are complex not only at the level of functional diversity (Gokul et al. 2016; Pittino et al. 2018) but also, as we have shown herein, in the distribution of organisms on a hole floor. The heterogeneous distribution on glaciers of grazers, which may feed on other biota, may mask our inference of interactions between organisms within the hole, and our general understanding of supraglacial ecosystem functioning. The distribution of invertebrates on a hole bottom probably mirrors heterogeneity of this ecosystem. For example, on Longyearbreen we observed a clear difference in the occurrence of tardigrade species representing various feeding modes. In cryoconite hole no. 3 microbivorous species was dominant in all subsamples but in cryoconite hole no. 2 herbivorous Hypsibius sp. was more abundant in four subsamples. On Forni (the Alps), 24 (per ml) tardigrades were determined in a sample taken from the middle of the cryoconite hole. Yet, another subsample from the same hole contained 84 tardigrades. The same phenomena exist in cryoconite holes where more than one group of animals coexists. When a subsample was taken from the 

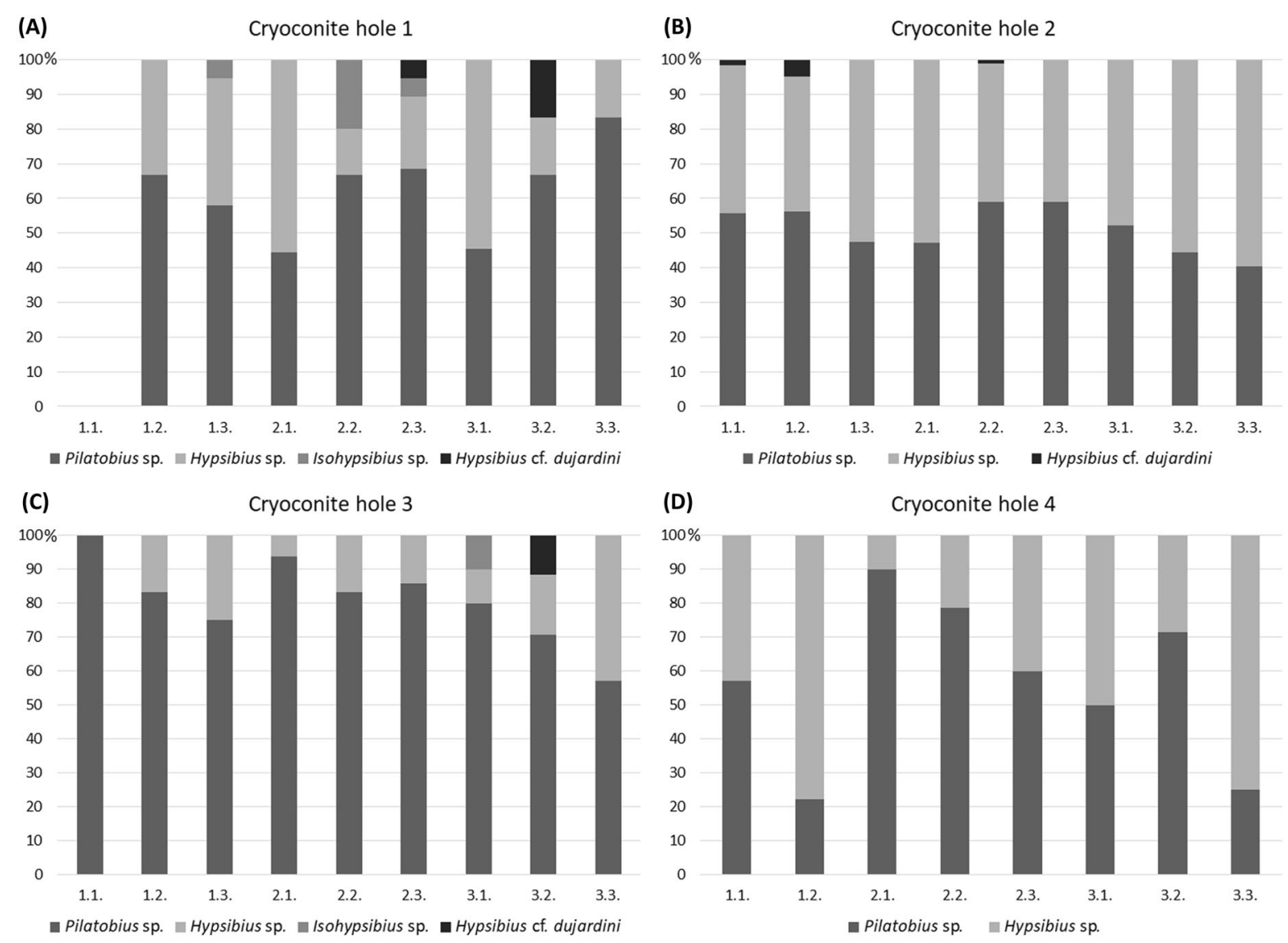

Fig. 4 The frequency of tardigrade species found in cryoconite holes on Longyearbreen. Numbers from 1.1. to 3.3. represent the ID of each subsample taken within each hole (see Fig. 2)

middle of a cryoconite hole on Longyearbreen (the Arctic), 30 tardigrades and 154 rotifers were found, but in the same hole the next subsample taken closer to the wall contained 52 tardigrades and 426 rotifers.

Differences in the distribution of invertebrates within cryoconite holes may depend on the characteristics of a specific animal group. Tardigrades, rotifers and mites found in this study differ in feeding modes, motility, size and shape (Nelson et al. 2015; Fontaneto and De Smet 2015; Marshall and Pugh 1996), potentially having a crucial role in locomotion as well as passive dispersal in the holes. Past studies on smallscale spatial distribution of invertebrates have yielded various, sometimes contradictory, results. The distribution of tardigrades in freshwater ecosystems is poorly understood. However, this issue has been studied in bryophytes (e.g. Wright 1991; Nelson and Adkins 2001; Degma et al. 2011; Young et al. 2018). Wright (1991) indicated that some (yet not all) tardigrade species actively migrate between moss layers because of moisture (Wright 1991). Other studies point to the fact that, in general, tardigrade distribution may be the result of migration of animals within the moss, not being influenced by moisture (Nelson and Adkins 2001). This implies that the distribution of invertebrates in moss cushions is likely to be influenced by the biology and behaviour of a particular species. However, the presence of tardigrades in samples may be random and their distribution may have a patchy character established by the founders of a colony as was also suggested in the literature (Degma et al. 2011; Meyer 2006). Taking into account the literature we consulted, the ability of tardigrades to actively migrate in moss cushions, and the fact that aquatic and limno-terrestrial tardigrades in laboratory cultures actively crawl on Petri dishes (personal observation), we may clearly state they may also actively move on a cryoconite hole bottom. 
Regarding rotifers, their distribution in mosses seems to be selective, and bdelloids appear to show spatial patterns (Fontaneto and Ricci 2006). Nevertheless, in terms of aquatic habitats, it is most probably random (Schmid-Araya 1993), with only scarce data for benthic species (Fontaneto and De Smet 2015). However, rotifers are also highly active in aquatic habitats. Locomotion in bdelloids is a typical leechlike creeping motion, and swimming is rather common (Ricci et al. 2001). The distribution of mites is more complex and depends on the type of environment, life history and feeding behaviour (Nielsen et al. 2012; Stoffels et al. 2003). Even though there are no data on the spatial distribution of mites in freshwater ecosystems, their active locomotion in both natural environments and laboratory cultures was observed (Miko 2016).

Random distribution may apply to invertebrates inhabiting cryoconite holes. For example, Zawierucha et al. (2018) provided evidence that invertebrates on the edge of the Greenland Ice Sheet are more common in cryoconite granules than in fine sediments. Observation on the erosion of granules by water flushing to mud suggests that fauna (tardigrades and rotifers) may be mechanically removed from the holes without any specific ecological relations with biotic variables (Zawierucha et al. 2018). Thus, invertebrate frequency and densities in, and between, cryoconite holes depend on typical random factors on glaciers such as melting, flushing and rain (Zawierucha et al. 2019), resulting in the disruption of these habitats and heterogeneity on a cryoconite hole floor, even in stable holes located in the upper part of glaciers tongues. Even though the invertebrates cannot be removed during rain or high ablation, their heterogeneous distribution on the hole bottom may result from inter-hole mixing. The effects of high meltwater production and open cryoconite holes in the Arctic and mountains (especially on the margin of the Greenland Ice Sheet and small glaciers) may influence the redistribution of cryoconite communities because of the so-called inter-hole watersediment mixing (Mueller et al. 2001; Mueller and Pollard 2004; Zawierucha et al. 2016b, 2019). The abovementioned explanation suggests that fine-scale distribution of invertebrates may result from stochastic events such as ecosystem disturbance by flushing water (Zawierucha et al. 2019) and animals' active movements.
Cook et al. (2015) suggested integrating different approaches for describing processes in supraglacial environments. As a result, a new term-biocryomorphology-was introduced. It refers to ice-organism interactions (Cook et al. 2015). The distribution and behaviour of organisms in stable cryoconite holes may influence their evolution as an effect of melting owing to heat from biological reactions (Cook et al. 2016a, b; Perkins et al. 2017). Therefore, heterogeneous spatial distribution of grazing invertebrates may exert an impact on ecological relations in holes and, consequently, primary production, organic matter distribution, and hole morphological evolution.

Studies on biota are often based on holes sampled once and may constitute snapshots, which could lead to certain general outcomes (Edwards et al. 2011; Franzetti et al. 2017b; Zawierucha et al. 2018) but hinder our understanding of cryoconite hole ecology. As we showed in this study, sampling a small amount of sediment could give biased estimates of small invertebrate abundance and diversity and may constitute a weak point of sampling protocols for wide cryoconite holes. Thus, future studies on biota would benefit from increasing the number of replicated samples taken from each cryoconite hole. As cryoconite holes differ within and between glaciers and geographical zones (Mueller and Pollard 2004; Stibal et al. 2010; Cook et al. 2015), more studies are needed to elaborate the most efficient sampling strategy and understanding probably hidden interactions and processes in cryoconite holes.

Acknowledgements We would like to thank anonymous reviewers who greatly improved the manuscript. Samplings in Svalbard and Antarctica were supported by the National Science Centre under Grant No. NCN 2013/11/N/NZ8/00597 awarded to K.Z. and Grant No. NCN 2015/17/B/NZ8/02475 awarded to M. Ronikier. M.B. was supported by NCN Grant No. 2017/24/C/ NZ8/00151. We would like to thank Maciej Wilk for his help during the sampling on Longyearbreen as well as Gracjan Robotnikowski for his help in samples analysis. Samples from the Blåisen Glacier were collected within the Grant [ETANGO] granted by INTERACT Transnational Access to K.Z. and J.B. The data from the Ecology Glacier used in the paper were collected based on Henryk Arctowski Polish Antarctic Station.

\section{Compliance with ethical standards}

Conflict of interest The authors declare that they have no conflict of interest.

Open Access This article is distributed under the terms of the Creative Commons Attribution 4.0 International License (http:// 
creativecommons.org/licenses/by/4.0/), which permits unrestricted use, distribution, and reproduction in any medium, provided you give appropriate credit to the original author(s) and the source, provide a link to the Creative Commons license, and indicate if changes were made.

\section{References}

Anesio AM, Laybourn-Parry J (2012) Glaciers and ice sheets as a biome. TrEE 4:219-225

Azzoni RS, Fugazza D, Zennaro M, Zucali M, D’Agata C, Maragno D, Cernuschi M, Smiraglia C, Diolaiuti GA (2017) Recent structural evolution of Forni Glacier tongue (Ortles-Cevedale Group, Central Italian Alps). J Maps 13:870-878

Bogdziewicz M, Crone EE, Steele MA, Zwolak R (2017) Effects of nitrogen deposition on reproduction in a masting tree: benefits of higher seed production are trumped by negative biotic interactions. J Ecol 105(2):310-320

Brooks ME, Kristensen K, van Benthem KJ, Magnusson A, Berg CW, Nielsen A, Skaug HJ, Maechler M, Bolker BM (2017) glmmTMB balances speed and flexibility among packages for zero-inflated generalized linear mixed modeling. R J 9(2):378-400

Cook J, Edwards A, Hubbard A (2015) Biocryomorphology: integrating microbial processes with ice surface hydrology, topography and roughness. Front Earth Sci 3:78

Cook JM, Edwards A, Bulling M, Mur LAJ, Cook S, Gokul JK, Cameron KA, Sweet M, Irvine-Fynn TDL (2016a) Metabolome-mediated biocryomorphic evolution promotes carbon fixation in Greenlandic cryoconite holes. Environ Microbiol. https://doi.org/10.1111/1462-2920.13349

Cook JM, Edwards A, Takeuchi N, Irvine-Fynn T (2016b) Cryoconite. The dark biological secret of the cryosphere. Prog Phys Geogr 40:1-46

Curtis TP, Sloan WT, Scannel JW (2002) Estimating prokaryotic diversity and its limits. Proc Natl Acad Sci USA 99:104914-110499

Dahl SO, Nesje A (1994) Holocene glacier fluctuations at Hardangerjøkulen, central-southern Norway: a high-resolution composite chronology from lacustrine and terrestrial deposits. The Holocene 4(3):269-277

Darcy JL, Gendron EMS, Sommers P, Porazinska DL, Schmidt SK (2018) Island biogeography of cryoconite hole bacteria in Antarctica's Taylor Valley and around the world. Front Ecol Evol 6:180. https://doi.org/10.3389/fevo.2018.00180

Dastych H (1980) Niesporczaki (Tardigrada) Tatrzanskiego Parku Narodowego. Monogr Fauny Polski 9:1-232

De Smet WH, Van Rompu EA (1994) Rotifera and Tardigrada from some cryoconite holes on a Spitsbergen (Svalbard) glacier. Belg J Zool 124:27-37

Degma P, Katina S, Sabatovičová L (2011) Horizontal distribution of moisture and Tardigrada in a single moss cushion. J Zool Syst Evol Res 49:71-77

Edwards A, Anesio AM, Rassner SM, Sattler B, Hubbard B, Perkins WT, Young M, Griffith GW (2011) Possible interactions between bacterial diversity, microbial activity and supraglacial hydrology of cryoconite holes in Svalbard. ISME J 5:150-160

Etzelmüller B, Ødegård RS, Vatne G, Mysterud RS, Tonning T, Sollid JL (2000) Glacier characteristics and sediment transfer system of Longyearbreen and Larsbreen, western Spitsbergen. Nor Geogr Tidsskr 54:157-168

Ferrario C, Pittino F, Tagliaferri I, Gandolfi I, Bestetti G, Azzoni RS, Diolaiuti G, Franzetti A, Ambrosini R, Villa S (2017) Bacteria contribute to pesticide degradation in cryoconite holes in an Alpine glacier. Environ Pollut 230:919-926

Fontaneto D, De Smet WH (2015) Rotifera, Chapter 4. In: Schmidt-Rhaesa A (ed) Handbook of zoology, gastrotricha, cycloneuralia and gnathifera. Gastrotricha and gnathifera. De Gruyter GmbH, Berlin, pp 217-300

Fontaneto D, Ricci C (2006) Spatial gradients in species diversity of microscopic animals: the case of bdelloid rotifers at high altitude. J Biogeogr 33:1305-1313

Forstmeier W, Wagenmakers EJ, Parker TH (2017) Detecting and avoiding likely false-positive findings-a practical guide. Biol Rev 92:1941-1968

Fountain A, Tranter M, Nylen TH, Lewis KJ, Mueller DR (2004) Evolution of cryoconite holes and their contribution to melt water runoff from glaciers in the McMurdo Dry Valleys, Antarctica. J Glaciol 50:35-45

Franklin RB, Mills AL (2003) Multi-scale variation in spatial heterogeneity for microbial community structure in an eastern Virginia agricultural field. FEMS Microbiol Ecol 44:335-346

Franklin RB, Blum LK, McComb A, Mills AL (2002) A geostatistical analysis of small-scale spatial variability in bacterial abundance and community structure in salt-marsh creek bank sediments. FEMS Microbiol Ecol 42:71-80

Franzetti F, Tagliaferri I, Gandolfi I, Bestetti G, Minora G, Mayer C, Azzoni RS, Diolaiuti G, Smiraglia C, Ambrosini R (2016) Light-dependent microbial metabolisms drive carbon fluxes on glacier surfaces. ISME J 10:2984

Franzetti A, Navarra F, Tagliaferri I, Gandolfi I, Bestetti G, Minora U et al (2017a) Potential sources of bacteria colonizing the cryoconite of an Alpine glacier. PLoS ONE 12(3):e0174786. https://doi.org/10.1371/journal.pone. 0174786

Franzetti A, Navarra F, Tagliaferri I, Gandolfi I, Bestetti G, Minora U, Azzoni RS, Diolaiuti G, Smiraglia C, Ambrosini $\mathrm{R}$ (2017b) Temporal variability of bacterial communities in cryoconite on an Alpine glacier. Environ Microbiol Rep 9:71-78

Gawor J, Grzesiak J, Sasin-Kurowska J, Borsuk P, Gromadka R, Górniak D, Świątecki A, Aleksandrzak-Piekarczyk T, Zdanowski MK (2016) Evidence of adaptation, niche separation and microevolution within the genus $\mathrm{Po}$ laromonas on Arctic and Antarctic glacial surfaces. Extremophiles 20:403-413

Gokul JK, Hodson AJ, Saetnan ER, Irvine-Fynn TD, Westall PJ, Detheridge AP, Takeuchi N, Bussell J, Mur LA, Edwards A (2016) Taxon interactions control the distributions of cryoconite bacteria colonizing a High Arctic ice cap. Mol Ecol 25:3752-3767

Green JL, Holmes AJ, Westoby M, Oliver I, Briscoe D, Dangerfield M, Gillings M, Beattie AJ (2004) Spatial scaling of microbial eukaryote diversity. Nature 432:747-750 
Grundmann GL, Debouzie D (2000) Geostatistical analysis of the distribution of $\mathrm{NH}_{4}{ }^{+}$and $\mathrm{NO}_{2}$ oxidizing bacteria and serotypes at the millimeter scale along a soil transect. FEMS Microbiol Ecol 34:57-62

Grzesiak J, Górniak D, Świątecki A, Aleksandrzak-Piekarczyk T, Szatraj K, Zdanowski MK (2015) Microbial community development on the surface of Hans and Werenskiold Glaciers (Svalbard, Arctic): a comparison. Extremophiles 19:885-897

Hodson A, Anesio AM, Ng F, Watson R, Quirk J, Irvine-Fynn T, Dye A, Clark Ch, McCloy P, Kohler J, Sattler B (2007) A glacier respires: quantifying the distribution and respiration $\mathrm{CO}_{2}$ flux of cryoconite across an entire Arctic supraglacial ecosystem. J Geophys Res 112(G4):G04S36

Hodson A, Anesio AM, Tranter M, Fountain A, Osborn M, Priscu J, Laybourn-Parry J, Sattler B (2008) Glacial ecosystems. Ecol Monogr 78:41-67

Kang S, Mills AL (2006) The effect of sample size in studies of soil microbial community structure. J Microbiol Methods 66:242-250

Koshima S (1987) Glacial biology and biotic communities. In: Kawano S, Connel JH, Hidaka T (eds) Evolution and coadaptation in biotic communities. Faculty of Science, Kyoto Univeristy, Kyoto, pp 76-92

Marshall DJ, Pugh PJ (1996) Origin of the inland Acari of Continental Antarctica, with particular reference to Dronning Maud Land. Zool J Linn Soc 118(2):101-118

Meyer HA (2006) Small-scale spatial distribution variability in terrestrial tardigrade populations. Hydrobiol 558:133-139

Mieczan TD, Górniak A, Swiątecki A, Zdanowski M, Tarkowska-Kukuryk M, Adamczuk M (2013) Vertical microzonation of ciliates in cryoconite holes in Ecology Glacier, King George Island. Pol Polar Res 34:201-212

Miko L (2016) Oribatid mites may actively migrate faster and over longer distances than anticipated: experimental evidence for Damaeus onustus (Acari: Oribatida). Soil Org 88:155-164

Mueller DR, Pollard WH (2004) Gradient analysis of cryoconite ecosystems from two polar glaciers. Pol Biol 27:66-74

Mueller DR, Vincent WF, Pollard WH, Fristen CH (2001) Glacial cryoconite ecosystems: a bipolar comparison of algal communities and habitats. Nova Hedwig Beih 123:173-197

Musilova M, Tranter M, Bennett SA, Wadham J, Anesio AM (2015) Stable microbial community composition on the Greenland Ice Sheet. Front Microbiol 6:193

Nelson DR, Adkins RG (2001) Distribution of tardigrades within a moss cushion: do tardigrades migrate in response to changing moisture conditions? Zool Anz 240:493-500

Nelson DR, Guidetti R, Rebecchi L (2015) Phylum tardigrada. In: Thorp J, Rogers DC (eds) Ecology and general biology. Academic Press, New York, pp 347-380

Nielsen UN, Osler GHR, Campbell CD, Burslem DFRP, van der Wal R (2012) Predictors of fine-scale spatial variation in soil mite and microbe community composition differ between biotic groups and habitats. Pedobiologia 55:83-91

Peacor SD, Werner EE (1997) Trait-mediated indirect interactions in a simple aquatic food web. Ecology 78(4):1146-1156

Perkins RG, Bagshaw E, Mol L, Williamson CJ, Fagan D, Gamble M, Yallop ML (2017) Photoacclimation by Arctic cryoconite phototrophs. FEMS Microbiol Ecol 93:fix018. https://doi.org/10.1093/femsec/fix018

Pętlicki M, Sziło J, MacDonell S, Vivero S, Bialik RJ (2017) Recent deceleration of the ice elevation change of ecology glacier (King George Island, Antarctica). Remote Sens 9(6):520. https://doi.org/10.3390/rs9060520

Pittino F, Maglio M, Gandolfi I, Azzoni RS, Diolaiuti G, Ambrosini R, Franzetti A (2018) Bacterial communities of cryoconite holes of a temperate alpine glacier show both seasonal trends and year-to-year variability. Ann Glaciol. https://doi.org/10.1017/aog.2018.16

Poniecka EA, Bagshaw EA, Tranter M, Sass H, Williamson CJ, Anesio AM, Black and Bloom Team (2018) Rapid development of anoxic niches in supraglacial ecosystems. Arct Antarct Alp Res 50(1):S100015. https://doi.org/10.1080/ 15230430.2017.1420859

Porazińska DL, Fountain AG, Nylen TH, Tranter M, Virginia RA, Wall DH (2004) The biodiversity and biogeochemistry of cryoconite holes from McMurdo dry valley glaciers, Antarctica. Arct Antarct Alp Res 36:84-91

R Core Team (2017) R: a language and environment for statistical computing. R Foundation for Statistical Computing, Vienna, Austria. https://www.Rproject.org/

Ricci C, Melone G, Walsh EJ (2001) A carnivorous bdelloid rotifer, Abrochtha carnivora n. sp. Invertebr Biol 120(2):136-141

Schmid-Araya JM (1993) Spatial distribution and population dynamics of a benthic rotifer, Embata laticeps (Murray) (Rotifera, Bdelloidea) in the bed sediments of a gravel brook. Fresh Biol 30:395-408

Schmitz OJ, Suttle KB (2001) Effects of top predator species on direct and indirect interactions in a food web. Ecology 82(7):2072-2081

Smith HJ, Foster RA, McKnight DM, Lisle JT, Littmann S, Kuypers MMM, Foreman CM (2017) Microbial formation of labile organic carbon in Antarctic glacial environments. Nat Geosci. https://doi.org/10.1038/ngeo2925

Sommers P, Darcy JL, Porazinska DL, Gendron EMS, Fountain AG, Zamora F, Vincent K, Cawley KM, Solon AJ, Vimercati L, Ryder J, Schmidt SK (2019) Comparison of microbial communities in the sediments and water columns of frozen cryoconite holes in the McMurdo Dry Valleys. Antarctica. Front Microbiol 10:65. https://doi.org/10.3389/ fmicb.2019.00065

Stec D, Smolak R, Kaczmarek Ł, Michalczyk Ł (2015) An integrative description of Macrobiotus paulinae sp. nov. (Tardigrada: Eutardigrada: Macrobiotidae: hufelandi group) from Kenya. Zootaxa 4052:501-526

Stec D, Gąsiorek P, Morek W, Kosztyła P, Zawierucha K, Michno K, Kaczmarek Ł, Prokop ZM, Michalczyk Ł (2016) Estimating optimal sample size for tardigrade morphometry. Zool J Linn Soc. https://doi.org/10.1111/ zoj.12404

Stibal M, Lawson EC, Lis GP, Mak KM, Wadham JL, Anesio AM (2010) Organic matter content and quality in supraglacial debris across the ablation zone of the Greenland ice sheet. Ann Glaciol 51:1-8

Stoffels RJ, Closs GP, Burns CW (2003) Multiple scales and the relationship between density and spatial aggregation in littoral zone communities. Oikos 103:81-92 
Takeuchi N, Kohshima S, Shiraiwa T, Kubota K (2001a) Characteristics of cryoconite (surface dust on glaciers) and surface albedo of a Patagonian glacier, Tyndall Glacier, Southern Patagonia Icefield. Bull Glaciol Res 18:65-69

Takeuchi N, Kohshima S, Seko K (2001b) Structure, formation, and darkening process of albedo-reducing material (cryoconite) on a Himalayan glacier: a granular algal mat growing on the glacier. Arct Antarct Alp Res 33:115-122

Uetake J, Nagatuska N, Onuma Y, Takeuchi N, Motoyama H, Aoki T (2019) Bacterial community changes with cryoconite granule size and their susceptibility to exogenous nutrients on 10 glaciers in northwestern Greenland. http:// dx.doi.org/10.1101/514083

Wharton RA, McKay CP, Simmons GM, Parker BC (1985) Cryoconite holes on glaciers. Bioscience 35:449-503

Wright JC (1991) The significance of four xeric parametres in the ecology of terrestrial Tardigrada. J Zool 224:59-77

Yallop ML, Anesio AM, Perkins RG, Cook J, Telling J, Fagan D, MacFarlane J, Stibal M, Baker G, Bellas C, Hodson A, Tranter M, Wadham J, Roberts NW (2012) Photophysiology and albedo-changing potential of the ice-algal community on the surface of the Greenland ice sheet. ISME J 6:2302-2313

Young AR, Miller JED, Villella J, Carey G, Miller WR (2018) Epiphyte type and sampling height impact mesofauna communities in Douglas-fir trees. Peer J 6:e5699. https:// doi.org/10.7717/peerj.5699
Zawierucha K, Kolicka M, Takeuchi N, Kaczmarek Ł (2015) What animals can live in cryoconite holes? A faunal review. J Zool 295:159-169

Zawierucha K, Ostrowska M, Vonnahme TR, Devetter M, Nawrot AP, Lehmann S, Kolicka M (2016a) Diversity and distribution of Tardigrada in Arctic cryoconite holes. J Limnol 75(3):545-559

Zawierucha K, Vonnahme TR, Devetter M, Kolicka M, Ostrowska M, Chmielewski S, Kosicki JZ (2016b) Area, depth and elevation of cryoconite holes in the Arctic do not influence Tardigrada densities. Pol Polar Res 37:325-334

Zawierucha K, Buda J, Pietryka M, Richter D, Łokas E, Lehmann-Konera S, Makowska N, Bogdziewicz M (2018) Snapshot of micro-animals and associated biotic and abiotic environmental variables on the edge of south-west Greenland ice sheet. Limnology 19:141-150

Zawierucha K, Buda J, Nawrot A (2019) Extreme weather event results in the removal of invertebrates from cryoconite holes on an Arctic valley glacier (Longyearbreen, Svalbard). Ecol Res. https://doi.org/10.1111/1440-1703.1276

Publisher's Note Springer Nature remains neutral with regard to jurisdictional claims in published maps and institutional affiliations. 